\title{
The Prevalence and Reasons of Tendency to Traditional Medicine
}

\author{
Jamshid Ayatollahi' ${ }^{1}$, Mahtab Eshaghi ${ }^{2}$, Seyed Alireza Mousavi ${ }^{1}$, Tahere Fallah ${ }^{3}$, Seyed Hossein \\ Shahcheraghi ${ }^{1^{*}}$ \\ ${ }^{1}$ Infectious Diseases Research Center, Shahid Sadoughi Hospital, Shahid Sadoughi University of Medical \\ Sciences, Yazd, Iran. \\ ${ }^{2}$ Medical student, Shahid Sadoughi University of Medical Sciences, Yazd, Iran.
}

${ }^{3}$ Expert of statistics, RDC center, Shahid Sadoughi Hospital, Shahid Sadoughi University of Medical Sciences, Yazd, Iran.

*Corresponding Author: Seyed Hossein Shahcheraghi, Infectious Diseases Research Center, Shahid Sadoughi Hospital, Shahid Sadoughi University of Medical Sciences, Yazd, Iran.

\begin{abstract}
Introduction: Complementary and alternative medicine refers to a group of medical, health, and medical care products that are typically other than conventional medicine (Western medicine). Due to the fact that the use of traditional medicine in Iran, like many other countries in the world, is expanding, the present study was conducted to investigate the prevalence and reasons for resorting to traditional medicine.

Methods: This study was performed on 370 clients of Baqaeipour Medical Center in Yazd Province. Sampling was made available and data collected by a researcher-made questionnaire. Data were analyzed by SPSS software version 23.

Results: The results of the present study showed that $97.3 \%$ of people chose traditional medicine after $89.2 \%$ due to lower cost and 87\% due to easy and faster access to traditional medicine. A significant point in this study was that a significant percentage of clients (44.6\%) believed that doctors did not give patients time and prescribed medication quickly. This means that patients are dissatisfied with the time a doctor prescribes for them.
\end{abstract}

Conclusion: Most of the reasons that people cite for turning to traditional and complementary medicine are pragmatic, in other words, they refer to the field of practical function. However, further studies are needed.

Keywords: Outbreaks; Causes of tendency; Yazd; Traditional Medicine

\section{INTRODUCTION}

Over the past hundred years, modern medicine has tried to dominate other types of medicine in the world, although this style of medicine, in addition to the achievements it has brought, has had serious consequences [1]. In addition, iatrogenic diseases or congenital diseases themselves constitute a huge volume of diseases in society [2, 3]. A significant number of patients in the United States face problems that are the result of treatment or adverse drug reactions $[3,4]$. Some researchers believe that people should be made aware of the instability and uncertainty of new medicine [5]. It is under the protection of such a medicine that many people not only are not treated, but also face problems in some cases [5]. On the other hand, there is much evidence of the rapid and widespread use of treatments such as complementary medicine in many countries $[6,7]$. 
In Iranian society, in recent decades, despite the widespread growth of technology and new technologies in the field of medicine, we are witnessing an increasing tendency of people in the community to use common treatments in traditional medicine and the like [8]. Although the country's officials are trying to organize it, but the level of public demand in this area is far from the official services provided [8, 9]. In general, dissatisfaction with the consequences of medical treatment, dissatisfaction with the physicianpatient relationship, and dissatisfaction with the socioeconomic relations of conventional medicine play an important role in the development of alternative medicine, especially traditional medicine [10-12].

The use of traditional medicine methods as therapeutic methods is increasing. But the standard of these methods and how they relate to the principles of conventional medicine are still unclear. Due to the high belief and interest of people and their high use of different methods of traditional medicine, it is necessary to conduct coherent research to investigate the reasons for the approach and determine the position of these methods in the treatment of patients and public health. The present study also pursues this goal.

\section{METHOD}

The present study was descriptive-analytical. Sampling was done by census of Baghaeipour clinic of Shahid Sadoughi University of Medical Sciences in Yazd in 2019. This study was also taken from the general doctoral student dissertation with the code of ethics IR.SSU. Medicine. REC.1399.001.

Inclusion criteria were those who referred to Baghaeipour clinic if they were satisfied to participate in the study and the dissatisfaction of people to participate in the study and failure to complete the questionnaires was the exclusion criteria.

In this study, a questionnaire containing 14 questions about the reasons for using and turning to traditional medicine treatments with a Likert scale with 5 options including strongly agree, agree, do not know, disagree and strongly disagree was designed and after explaining to the clients, by They were completed (If the patient was able to complete the questionnaire, the patient himself and in cases such as children from their companions would be completed). Other demographic information including age, sex, occupation, place of residence, education and clinic line they visited were also completed in the questionnaire.

All patients referred to the clinic were included in the study until the required sample size (370 people) was completed and were excluded from the study if the questionnaire data were incomplete. While maintaining patient confidentiality under the Helsinki Convention, individuals were assured that their information would be confidential and would only be used for research purposes. Also, in the implementation of this study, no additional costs were incurred by the participants. Finally, the obtained information was entered into SPSS software version 23 and analyzed by statistical methods including descriptive statistics (frequency indices and relative percentage) and Chi-square statistical test. Significance level was also considered 0.05 .

\section{RESULTS}

In this study, 370 people were studied. The mean age of patients was 48.01 years with a standard deviation of 11.42 years and the range of changes was 25 to 74 years.

Among the patients, 179 (48.4\%) were male and 191 (51.6\%) were female. 237 patients (64.1\%) were natives and 133 patients (35.9\%) were non-natives.

In terms of education, 28 people (7.6\%) are illiterate, 50 people (13.5\%) have a cycle, 165 people (44.6\%) have a diploma, 7 people $(1.9 \%)$ have a postgraduate degree, 96 people (25.9\%) had a bachelor's degree and $24(6.5 \%)$ had a master's degree.

Occupationally, most of the patients referred to the clinic were housewives, freelancers and employees with a frequency of $30.3 \%, 26.2 \%$ and $16.8 \%$, respectively.

The highest number of referrals to the clinic was related to pediatric, ocular, ENT, and endocrine lines with a frequency of $9.7 \%, 8.1 \%, 7.8 \%$ and $7 \%$, respectively. The number of referrals to traditional medicine was $6.8 \%$.

The results of the questionnaires of the reasons for turning to traditional medicine treatments (frequency) are shown in Table 1: 
The Prevalence and Reasons of Tendency to Traditional Medicine

Table1. Frequency distribution of results related to the questionnaire of the reasons for turning to traditional medicine

\begin{tabular}{|c|c|c|c|c|c|c|c|}
\hline & Question & & $\begin{array}{l}\text { I quite } \\
\text { agree }\end{array}$ & \begin{tabular}{|l|} 
\\
agree
\end{tabular} & $\begin{array}{l}\text { I do not } \\
\text { know }\end{array}$ & $\begin{array}{l}\text { I } \\
\text { disagree }\end{array}$ & $\begin{array}{l}\text { I } \\
\text { completely } \\
\text { disagree }\end{array}$ \\
\hline 1 & $\begin{array}{l}\text { Because the doctors' prescription } \\
\text { drugs did not work to cure my } \\
\text { disease. }\end{array}$ & \begin{tabular}{|l|} 
Frequency \\
Percent $(\%)$
\end{tabular} & $\begin{array}{l}27 \\
7.3\end{array}$ & $\begin{array}{l}258 \\
69.7\end{array}$ & $\begin{array}{l}9 \\
2.4\end{array}$ & $\begin{array}{l}74 \\
20\end{array}$ & $\begin{array}{l}2 \\
0.5\end{array}$ \\
\hline 2 & $\begin{array}{l}\text { Because doctors do not make time } \\
\text { for the patient at all and prescribe } \\
\text { medication quickly. }\end{array}$ & \begin{tabular}{|l|} 
Frequency \\
Percent $(\%)$
\end{tabular} & $\begin{array}{l}11 \\
3\end{array}$ & $\begin{array}{l}154 \\
41.6\end{array}$ & $\begin{array}{l}8 \\
2.2\end{array}$ & $\begin{array}{l}188 \\
50.8\end{array}$ & $\begin{array}{l}9 \\
2.4\end{array}$ \\
\hline 3 & $\begin{array}{l}\text { Because I am more confident in } \\
\text { natural methods. }\end{array}$ & \begin{tabular}{|l|} 
Frequency \\
Percent (\%)
\end{tabular} & $\begin{array}{l}27 \\
7.3\end{array}$ & $\begin{array}{l}211 \\
57\end{array}$ & $\begin{array}{l}48 \\
13\end{array}$ & $\begin{array}{l}76 \\
20.5\end{array}$ & $\begin{array}{l}7 \\
1.9\end{array}$ \\
\hline 4 & $\begin{array}{l}\text { Because in this method, he/she also } \\
\text { pays attention to religious advice. }\end{array}$ & \begin{tabular}{|l|} 
Frequency \\
Percent $(\%)$
\end{tabular} & $\begin{array}{l}5 \\
1.4\end{array}$ & $\begin{array}{l}87 \\
23.5 \\
\end{array}$ & $\begin{array}{l}122 \\
33\end{array}$ & $\begin{array}{l}150 \\
40.5\end{array}$ & $\begin{array}{l}6 \\
1.6 \\
\end{array}$ \\
\hline 5 & $\begin{array}{l}\text { Because the costs of conventional } \\
\text { medical procedures are higher. }\end{array}$ & \begin{tabular}{|l|} 
Frequency \\
Percent (\%)
\end{tabular} & $\begin{array}{l}122 \\
33\end{array}$ & $\begin{array}{l}208 \\
56.2\end{array}$ & $\begin{array}{l}7 \\
1.9\end{array}$ & $\begin{array}{l}32 \\
8.6\end{array}$ & $\begin{array}{ll}1 \\
0.3\end{array}$ \\
\hline 6 & $\begin{array}{l}\text { Because I saw a lot of people who } \\
\text { get results from this method and } \\
\text { recommends it to others. }\end{array}$ & \begin{tabular}{|l|} 
Frequency \\
Percent $(\%)$
\end{tabular} & $\begin{array}{l}171 \\
46.2\end{array}$ & $\begin{array}{l}189 \\
51.1\end{array}$ & \begin{tabular}{|l|}
9 \\
2.4
\end{tabular} & $\begin{array}{l}1 \\
0.3 \\
\end{array}$ & $\begin{array}{l}0 \\
0\end{array}$ \\
\hline 7 & $\begin{array}{l}\text { Because it is a Western scientific } \\
\text { medicine that does not look at } \\
\text { Islamic man. }\end{array}$ & \begin{tabular}{|l|} 
Frequency \\
Percent $(\%)$
\end{tabular} & $\begin{array}{l}10 \\
2.7\end{array}$ & $\begin{array}{l}27 \\
7.3\end{array}$ & $\begin{array}{l}167 \\
45.1\end{array}$ & $\begin{array}{l}147 \\
39.7\end{array}$ & $\begin{array}{l}19 \\
5.1\end{array}$ \\
\hline 8 & $\begin{array}{l}\text { Because the drugs used in modern } \\
\text { medicine cause many dependencies } \\
\text { and side effects. }\end{array}$ & \begin{tabular}{|l|} 
Frequency \\
Percent (\%)
\end{tabular} & $\begin{array}{l}4 \\
1.1\end{array}$ & $\begin{array}{l}269 \\
72.7\end{array}$ & \begin{tabular}{|l|}
54 \\
14.6
\end{tabular} & \begin{tabular}{|l|}
41 \\
11.1
\end{tabular} & $\begin{array}{l}2 \\
0.5\end{array}$ \\
\hline 9 & $\begin{array}{l}\text { Because in traditional medicine, } \\
\text { in addition to treatment, it also } \\
\text { improves lifestyle. }\end{array}$ & $\begin{array}{l}\text { Frequency } \\
\text { Percent (\%) }\end{array}$ & $\begin{array}{l}16 \\
4.3\end{array}$ & $\begin{array}{l}240 \\
64.9\end{array}$ & $\begin{array}{l}100 \\
27\end{array}$ & $\begin{array}{l}11 \\
3\end{array}$ & \begin{tabular}{|l|}
3 \\
0.8
\end{tabular} \\
\hline 10 & $\begin{array}{l}\text { Because access to treatments in } \\
\text { traditional medicine is easier and } \\
\text { faster. }\end{array}$ & \begin{tabular}{|l|} 
Frequency \\
Percent (\%)
\end{tabular} & $\begin{array}{l}51 \\
13.8\end{array}$ & $\begin{array}{l}271 \\
73.2\end{array}$ & $\begin{array}{l}11 \\
3\end{array}$ & $\begin{array}{l}36 \\
9.7\end{array}$ & \begin{tabular}{|l|}
1 \\
0.3
\end{tabular} \\
\hline 11 & $\begin{array}{l}\text { Because traditional medicine, unlike } \\
\text { modern medicine, is not dependent } \\
\text { on experimentation and imaging. }\end{array}$ & \begin{tabular}{|l|} 
Frequency \\
Percent (\%)
\end{tabular} & $\begin{array}{l}96 \\
25.9\end{array}$ & $\begin{array}{l}187 \\
50.5\end{array}$ & \begin{tabular}{|l|}
44 \\
11.9
\end{tabular} & $\begin{array}{l}35 \\
9.5\end{array}$ & \begin{tabular}{|l|}
8 \\
2.2
\end{tabular} \\
\hline 12 & $\begin{array}{l}\text { Because drugs used in traditional } \\
\text { medicine are harmless if used } \\
\text { incorrectly, unlike modern medicine. }\end{array}$ & \begin{tabular}{|l|} 
Frequency \\
Percent $(\%)$
\end{tabular} & $\begin{array}{l}32 \\
8.6\end{array}$ & $\begin{array}{l}175 \\
47.3\end{array}$ & $\begin{array}{l}129 \\
34.9\end{array}$ & $\begin{array}{l}34 \\
9.2\end{array}$ & $\begin{array}{l}0 \\
0\end{array}$ \\
\hline 13 & $\begin{array}{l}\text { Because the method of treatment in } \\
\text { traditional medicine is climatic and } \\
\text { indigenous, unlike modern medicine, } \\
\text { which is general and universal. }\end{array}$ & \begin{tabular}{|l|} 
Frequency \\
Percent $(\%)$
\end{tabular} & $\begin{array}{l}12 \\
3.2\end{array}$ & $\begin{array}{l}108 \\
29.2\end{array}$ & $\begin{array}{l}157 \\
42.4\end{array}$ & \begin{tabular}{|l|}
88 \\
23.8
\end{tabular} & \begin{tabular}{|l|}
5 \\
1.4
\end{tabular} \\
\hline 14 & $\begin{array}{l}\text { Because traditional medicine } \\
\text { methods prevent getting sick, but } \\
\text { modern medicine is more about } \\
\text { treating the disease. }\end{array}$ & \begin{tabular}{|l|} 
Frequency \\
Percent (\%)
\end{tabular} & \begin{tabular}{|l|}
4 \\
1.1
\end{tabular} & $\begin{array}{l}160 \\
43.2\end{array}$ & \begin{tabular}{|l|}
131 \\
35.4
\end{tabular} & \begin{tabular}{|l|}
72 \\
19.5
\end{tabular} & \begin{tabular}{|l|}
3 \\
0.8
\end{tabular} \\
\hline
\end{tabular}

Open Access Journal of Internal Medicine V3 . I1 . 2020 
The Prevalence and Reasons of Tendency to Traditional Medicine

The most common causes of overhaul were related to the question "because I have seen many people who get results from this method and recommend it to others" with a frequency of $97.3 \%$, "because the costs of conventional medical methods are higher. "With a frequency of $89.2 \%$, "because access to treatments in traditional medicine is easier and faster." With a frequency of $87 \%$ and "because traditional medicine, unlike modern medicine, is not dependent on experimentation and imaging." It has a frequency of
$76.4 \%$ and these items have the most agreement and are one of the most common reasons for turning to traditional medicine treatments. One of the highlights of the study was the question "because doctors do not spend time with patients at all and prescribe medication quickly." $44.6 \%$ agreed and this means that patients are dissatisfied with the time allotted to them by the doctor.

The reason for the desire for traditional medicine based on the sex parameter is also given in Table 2:

Table2. Reasons for the desire for traditional medicine treatments based on the sex

\begin{tabular}{|c|c|c|c|c|c|c|c|}
\hline & Question & & $\begin{array}{l}\text { I quite agree } \\
\text { (male) [female] }\end{array}$ & \begin{tabular}{|l} 
I agree \\
(male) \\
{$[$ female] }
\end{tabular} & \begin{tabular}{|l|} 
I do not \\
know \\
(male) \\
female] \\
\end{tabular} & \begin{tabular}{|l} 
I disagree \\
(male) \\
{$[$ female $]$}
\end{tabular} & \begin{tabular}{|l|} 
I completely \\
disagree \\
(male) \\
{$[$ female] } \\
\end{tabular} \\
\hline 1 & \begin{tabular}{|l|} 
Because the doctors' \\
prescription drugs did not \\
work to cure my disease.
\end{tabular} & $\begin{array}{l}\text { Frequency } \\
\text { Percent (\%) }\end{array}$ & $\begin{array}{l}(17)[10] \\
(9.5)[5.2]\end{array}$ & $\begin{array}{l}(114)[144] \\
(63.7)[75.4]\end{array}$ & \begin{tabular}{|l}
$\mid 1)[8]$ \\
$(0.6)[4.2]$
\end{tabular} & \begin{tabular}{|l}
$(45)[29]$ \\
$(25.1)[15.2]$
\end{tabular} & $\begin{array}{l}(2)[0] \\
(1.1)[0]\end{array}$ \\
\hline 2 & $\begin{array}{l}\text { Because doctors do not } \\
\text { make time for the patient } \\
\text { at all and prescribe } \\
\text { medication quickly. }\end{array}$ & \begin{tabular}{|l|} 
Frequency \\
Percent (\%)
\end{tabular} & \begin{tabular}{|l}
1 (1) [10] \\
$(0.6)[5.2]$
\end{tabular} & \begin{tabular}{|l}
$(74)[80]$ \\
$(41.3)[41.9]$
\end{tabular} & \begin{tabular}{|l}
$5)[3]$ \\
$(2.8)[1.6]$
\end{tabular} & \begin{tabular}{|l|}
$95)$ [93] \\
$(53.1)$ [48.7]
\end{tabular} & \begin{tabular}{|l}
$4)[5]$ \\
$(2.2)[2.6]$
\end{tabular} \\
\hline 3 & $\begin{array}{l}\text { Because I am more } \\
\text { confident in natural } \\
\text { methods. }\end{array}$ & $\begin{array}{l}\text { Frequency } \\
\text { Percent (\%) }\end{array}$ & $\begin{array}{l}\text { (9) }[18] \\
(5)[9.4]\end{array}$ & $\begin{array}{l}(118)[93] \\
(65.9)[48.7]\end{array}$ & $\begin{array}{l}\text { (17) [32] } \\
(9)[16.8]\end{array}$ & \begin{tabular}{|l}
$(33)[43]$ \\
$(18.4)[22.5]$
\end{tabular} & \begin{tabular}{|l} 
(2) [5] \\
$(1.1)[2.6]$
\end{tabular} \\
\hline 4 & $\begin{array}{l}\text { Because in this method, } \\
\text { he/she also pays attention } \\
\text { to religious advice. }\end{array}$ & \begin{tabular}{|l|} 
Frequency \\
Percent (\%)
\end{tabular} & $\begin{array}{l}(1)[4] \\
(0.6)[2.1]\end{array}$ & \begin{tabular}{|l}
$53)[34]$ \\
$(29.6)[17.8]$
\end{tabular} & \begin{tabular}{|l|}
$55)[67]$ \\
$(30.7)[35.1]$
\end{tabular} & $\begin{array}{l}(68)[82] \\
(38)[42.9]\end{array}$ & $\begin{array}{l}(2)[4] \\
(1.1)[2.1]\end{array}$ \\
\hline 5 & $\begin{array}{l}\text { Because the costs of } \\
\text { conventional medical } \\
\text { procedures are higher. }\end{array}$ & \begin{tabular}{|l|} 
Frequency \\
Percent (\%)
\end{tabular} & \begin{tabular}{|l}
$58)[64]$ \\
$(32.4)$ [33.5]
\end{tabular} & \begin{tabular}{|l}
$96)[112]$ \\
$(53.6)[58.6]$
\end{tabular} & $\begin{array}{l}(2)[5] \\
(1.1)[2.6]\end{array}$ & $\begin{array}{l}(23)[9] \\
(12.8)[4.7]\end{array}$ & \begin{tabular}{|l}
$0)[1]$ \\
$(0)[0.5]$
\end{tabular} \\
\hline 6 & $\begin{array}{l}\text { Because I saw a lot of } \\
\text { people who get results } \\
\text { from this method and } \\
\text { recommends it to others. }\end{array}$ & \begin{tabular}{|l|} 
Frequency \\
Percent (\%)
\end{tabular} & \begin{tabular}{|l}
$76)[95]$ \\
$(42.5)[49.7]$
\end{tabular} & \begin{tabular}{|l}
$97)[92]$ \\
$(54.2)[48.2]$
\end{tabular} & $\begin{array}{l}(6)[3] \\
(3.4)[1.6]\end{array}$ & $\begin{array}{l}(0)[1] \\
(0)[0.5]\end{array}$ & $\begin{array}{l}(0)[0] \\
(0)[0]\end{array}$ \\
\hline 7 & $\begin{array}{l}\text { Because it is a Western } \\
\text { scientific medicine that } \\
\text { does not look at Islamic } \\
\text { man. }\end{array}$ & \begin{tabular}{|l|} 
Frequency \\
Percent (\%)
\end{tabular} & $\begin{array}{l}(3)[7] \\
(1.7)[3.7]\end{array}$ & $\begin{array}{l}(14)[13] \\
(7.8)[6.8]\end{array}$ & $\begin{array}{l}(77)[90] \\
(43)[47.1]\end{array}$ & \begin{tabular}{|l|}
$74)[73]$ \\
$(41.3)[38.2]$
\end{tabular} & $\begin{array}{l}(11)[8] \\
(6.1)[4.2]\end{array}$ \\
\hline 8 & $\begin{array}{l}\text { Because the drugs used in } \\
\text { modern medicine cause } \\
\text { many dependencies and } \\
\text { side effects. }\end{array}$ & \begin{tabular}{|l|} 
Frequency \\
Percent (\%)
\end{tabular} & $\begin{array}{l}(2)[2] \\
(1.1)[1]\end{array}$ & \begin{tabular}{|l}
$(133)[136]$ \\
$(74.3)[71.2]$
\end{tabular} & \begin{tabular}{|l|}
$27)[27]$ \\
$(15.1)[14.1]$
\end{tabular} & $\begin{array}{l}(15)[26] \\
(8.4)[13.6]\end{array}$ & \begin{tabular}{|l}
$2)[0]$ \\
$(1.1)[0]$
\end{tabular} \\
\hline 9 & $\begin{array}{l}\text { Because in traditional } \\
\text { medicine, in addition to } \\
\text { treatment, it also improves } \\
\text { lifestyle. }\end{array}$ & $\begin{array}{l}\text { Frequency } \\
\text { Percent (\%) }\end{array}$ & \begin{tabular}{|l} 
(5) [11] \\
$(2.8)[5.8]$
\end{tabular} & $\mid \begin{array}{l}(121)[119] \\
(67.6)[62.3]\end{array}$ & $\mid \begin{array}{l}(46)[54] \\
(25.7)[28.3]\end{array}$ & \begin{tabular}{|l} 
(6) [5] \\
$(3.4)[2.6]$
\end{tabular} & $\begin{array}{l}(1)[2] \\
(0.6)[1]\end{array}$ \\
\hline
\end{tabular}


The Prevalence and Reasons of Tendency to Traditional Medicine

\begin{tabular}{|c|c|c|c|c|c|c|c|}
\hline 10 & $\begin{array}{l}\text { Because access to } \\
\text { treatments in traditional } \\
\text { medicine is easier and } \\
\text { faster. }\end{array}$ & $\begin{array}{l}\text { Frequency } \\
\text { Percent (\%) }\end{array}$ & $\begin{array}{l}(29)[22] \\
(16.2)[11.5]\end{array}$ & $\begin{array}{l}(128)[143] \\
(71.5)[74.9]\end{array}$ & $\begin{array}{l}(6)[5] \\
(3.4)[2.6]\end{array}$ & $\begin{array}{l}(15)[21] \\
(8.4)[11]\end{array}$ & $\begin{array}{l}(1)[0] \\
(0.6)[0]\end{array}$ \\
\hline 11 & $\begin{array}{l}\text { Because traditional } \\
\text { medicine, unlike modern } \\
\text { medicine, is not dependent } \\
\text { on experimentation and } \\
\text { imaging. }\end{array}$ & $\begin{array}{l}\text { Frequency } \\
\text { Percent (\%) }\end{array}$ & $\begin{array}{l}(50)[46] \\
(27.9)[24.1]\end{array}$ & $\begin{array}{l}(89)[98] \\
(49.7)[51.3]\end{array}$ & $\begin{array}{l}(23)[21] \\
(12.8)[11]\end{array}$ & $\begin{array}{l}(17)[18] \\
(9.5)[9.4]\end{array}$ & $\begin{array}{l}(0)[8] \\
(0)[4.2]\end{array}$ \\
\hline 12 & $\begin{array}{l}\text { Because drugs used in } \\
\text { traditional medicine } \\
\text { are harmless if used } \\
\text { incorrectly, unlike modern } \\
\text { medicine. }\end{array}$ & $\begin{array}{l}\text { Frequency } \\
\text { Percent (\%) }\end{array}$ & $\begin{array}{l}(24)[8] \\
(13.4)[4.2]\end{array}$ & $\begin{array}{l}(82)[93] \\
(45.8)[48.7]\end{array}$ & $\begin{array}{l}(52)[77] \\
(29.1)[40.3]\end{array}$ & $\begin{array}{l}(21)[13] \\
(11.7)[6.8]\end{array}$ & $\begin{array}{l}(0)[0] \\
(0)[0]\end{array}$ \\
\hline 13 & $\begin{array}{l}\text { Because the method of } \\
\text { treatment in traditional } \\
\text { medicine is climatic and } \\
\text { indigenous, unlike modern } \\
\text { medicine, which is general } \\
\text { and universal. }\end{array}$ & $\begin{array}{l}\text { Frequency } \\
\text { Percent (\%) }\end{array}$ & $\begin{array}{l}(6)[6] \\
(3.4)[3.1]\end{array}$ & $\begin{array}{l}(56)[52] \\
(31.3)[27.2]\end{array}$ & $\begin{array}{l}(75)[82] \\
(41.9)[42.9]\end{array}$ & $\begin{array}{l}(41)[47] \\
(22.9)[24.6]\end{array}$ & $\begin{array}{l}(1)[4] \\
(0.6)[2.1]\end{array}$ \\
\hline 14 & $\begin{array}{l}\text { Because traditional } \\
\text { medicine methods prevent } \\
\text { getting sick, but modern } \\
\text { medicine is more about } \\
\text { treating the disease. }\end{array}$ & $\begin{array}{l}\text { Frequency } \\
\text { Percent (\%) }\end{array}$ & $\begin{array}{l}(3)[1] \\
(1.7)[0.5]\end{array}$ & $\begin{array}{l}(80)[80] \\
(44.7)[41.9]\end{array}$ & $\begin{array}{l}(62)[69] \\
(34.6)[36.1]\end{array}$ & $\begin{array}{l}(33)[39] \\
(18.4)[20.4]\end{array}$ & $\begin{array}{l}(1)[2] \\
(0.6)[1]\end{array}$ \\
\hline
\end{tabular}

\section{DISCUSSION}

Complementary and alternative medicine refers to a group of medical, health care and products that are not normally part of conventional medicine (Western medicine) [13]. Today, these methods, along with conventional medicine, are widely used to treat and restore health to sick people and prevent disease in healthy people [14]. Some studies on the effectiveness of these methods on neck and back pain have confirmed their true effect [15], However, complementary medicine could not reduce the subsequent disabilities related to these pains compared to the control group [15]. A study in which a number of randomized clinical trials were performed with the help of complementary medicine showed that traditional methods are effective in treating patients' complaints (16 positive effect studies, 11 unspecified effect studies and 7 negative effects) [16]. Traditional, complementary or alternative medicine methods have been developed in areas with different cultures. For this reason, standards and their evaluation methods have not been sufficiently developed, both at the national and international levels $[17,18]$. Important advantages of this medicine and the reasons for the significant acceptance of these methods by the people can be the direct effects of these methods as well as their cultural and historical context in the country, limitations in medical science and also limitations and shortcomings in the service delivery system. Medicine and more acceptable time and treatment costs mentioned [19].

The results of the present study showed that $97.3 \%$ of people used traditional medicine due to the recommendation of others and about $89.2 \%$ chose this method due to lower cost and $87 \%$ due to easier and faster access. The noteworthy point in this study was that a significant percentage of patients (44.6\%) believed that doctors do not spend time for the patient and prescribe medication quickly. The results of the present study showed that in the study population the majority of clients were women, which was the same in most studies $[18,19]$. Most of them also had diploma and bachelor's degrees. Most of the clients were also housewives, self-employed and employees.

In a study conducted in Isfahan, testing traditional 
medicine and preventing the side effects of chemical drugs was the most motivated by traditional medicine patients. People are worried about the side effects of common medicines on the one hand, they reduce their consumption, but on the other hand, it can cause treatment failure by not using them properly. In the present study, $55.9 \%$ of people mentioned the safety of traditional medicine [18].

In the study of Rossi et al., The effectiveness of complementary medicine on cluster headaches was observed and patients' satisfaction with the complementary medicine received and treatment costs were shown [20]. The findings of one study, like the present study, showed that a high percentage of clients were aware of the traditional medicine method through friends and acquaintances [18]. Ramezani et al. In investigating the reasons for resorting to alternative therapies, the most common reason for resorting to alternative therapies was the recommendation of other people $(60 \%)$ and the ineffectiveness of prescription drugs (52\%). In their study, 39\% of people believed that doctors did not spend enough time for the patient and prescribe medication quickly, which was $44.6 \%$ in the present study [21]. Also, in the study of complementary and traditional medicine methods in Tehran, it was shown that increasing people's awareness about traditional methods and increasing the number of centers providing this method has been effective in increasing the use of these methods [22]. Unlike the present study, which did not evaluate the methods of traditional medicine, in the study, the highest use was related to phytotherapy, cupping and acupuncture [22]. In the study of Sedighi et al. In Tehran, among 4123 people, it was shown that the most knowledge and use is related to herbal medicine [23]. The results of research by Zafar Ghandi et al. Also showed that phytotherapy and cupping have been most welcomed [24]. The frequency of using complementary and traditional medicine methods in the residents of Tehran was the research of Tehrani et al. With a sample size of 6147 people in 30 neighborhoods of Tehran, which showed that the highest level of knowledge and use was allocated to herbal medicines [22]. In some cases, despite the lack of knowledge about the treatment method, the use of these treatments has been significant. For example, in the study of Zafar Ghandi et al., although only $26.3 \%$ of the clients of the medical centers were aware of the branches of Iranian traditional medicine, 69\% had used at least one of the methods of traditional medicine [24]. Therefore, people are not aware of the Iranian traditional medicine school and the attitude and reason for resorting to these treatments is based on personal experiences or therapeutic experiences of those around them and interest in traditional medicine and its use is still high despite the increasing progress of conventional medicine.

\section{REFERENCES}

[1] Dong Y, Liao J, Yao K, Jiang W, Wang J (2017) Application of traditional Chinese medicine in treatment of atrial fibrillation. Evid Based Complement Alternat Med. 2017.

[2] Corson TW, Crews CM (2007) Molecular understanding and modern application of traditional medicines: triumphs and trials. Cell. 130 (5):769-74.

[3] Li M, Qiao C, Qin L, Zhang J, Ling C (2012) Application of traditional Chinese medicine injection in treatment of primary liver cancer: a review. J Tradit Chin Med 32(3):299-307.

[4] Mamedov N, Mehdiyeva N, Craker LE (2015) Medicinal plants used in traditional medicine of the Caucasus and North America. Journal of Medicinally Active Plants. 4 (3):42-66.

[5] Barratt A, Wyer PC, Hatala R, McGinn T, Dans AL, Keitz S, et al. (2004) Tips for learners of evidencebased medicine: 1. Relative risk reduction, absolute risk reduction and number needed to treat. CMAJ 171(4):353-8.

[6] Yuan H, Ma Q, Ye L, Piao G (2016) The traditional medicine and modern medicine from natural products. Molecules 21(5):559.

[7] Barnes J, McLachlan AJ, Sherwin CM, Enioutina EY (2016) Herbal medicines: challenges in the modern world. Part 1. Australia and New Zealand. Expert Rev Clin Pharmacol 9(7):905-15.

[8] Ameri A, Heydarirad G, Mahdavi Jafari J, Ghobadi A, Rezaeizadeh H, Choopani R (2015) Medicinal plants contain mucilage used in traditional Persian medicine (TPM). Pharm Biol 53(4):61523.

[9] Niroumand MC, Farzaei MH, Razkenari EK, Amin G, Khanavi M, Akbarzadeh T, et al (2016) An evidence-based review on medicinal plants used 
The Prevalence and Reasons of Tendency to Traditional Medicine

as insecticide and insect repellent in traditional Iranian medicine. Iranian Red Crescent Medical Journal 18 (2).

[10] Alijaniha F, Ghaffari F, Naseri M (2013) Smelling drugs application, in the prevention and treatment of disease, from the perspective of Iranian traditional medicine. Medical History Journal 5(14):67-77.

[11] Mojahedi M, Naseri M, Majdzadeh R, Keshavarz M, Ebadini M, Nazem E, et al (2014) Reliability and validity assessment of Mizaj questionnaire: a novel self-report scale in Iranian traditional medicine. Iranian Red Crescent Medical Journal 16 (3).

[12] Amirghofran Z (2010) Medicinal plants as immunosuppressive agents in traditional Iranian medicine. Iran J Immunol 7 (2):65-73.

[13] Cui H-T, Li Y-T, Guo L-Y, Liu X-G, Wang L-S, Jia J-W, et al. (2020) Traditional Chinese medicine for treatment of coronavirus disease 2019: a review. Traditional Medicine Research 5 (2):65-73.

[14] Organization WH (2012) The regional strategy for traditional medicine in the Western Pacific (2011-2020).

[15] Furlan AD, Yazdi F, Tsertsvadze A, Gross A, Van Tulder M, Santaguida L, et al (2012) A systematic review and meta-analysis of efficacy, cost-effectiveness, and safety of selected complementary and alternative medicine for neck and low-back pain. Evid Based Complement Alternat Med 2012.

[16] Ernst E (2003) Complementary medicine: where is the evidence? J Fam Pract 52 (8):630-6.

[17] Bodeker G, Graz B (2020) Traditional medicine. Hunter's Tropical Medicine and Emerging Infectious Diseases: Elsevier 194-199.
[18] Mahmoudian A, Golshiri P, Rezaei G, Akbari M (2012) Patients' Satisfaction form Iranian Traditional Medicine. Journal of Isfahan Medical School 30 (208).

[19] AzinS,NooraiiS, MoshkaniZ(2010)Complementary/ alternative medicine: knowledge, attitudes and practice among general practitioners in Tehran, Iran. Iranian Journal of Pharmaceutical Research 27-31.

[20] Rossi P, Torelli P, Di Lorenzo C, Sances G, Manzoni GC, Tassorelli C, et al. (2008) Use of complementary and alternative medicine by patients with cluster headache: results of a multicentre headache clinic survey. Complement Ther Med 16 (4):220-7.

[21] Ramezani R, Ramezani S (2017) Survey of Spread and Reasons of Turning into Alternative Therapies to Current Medicine:(Case Study of Tehran). Alborz University Medical Journal 6 (3):187-98.

[22] SA TB, Asgharifard H, Haghdoost A, Barghmadi M, Mohammadhosseini N (2008) The use of Complementary/Alternative Medicine among the general population in Tehran, Iran. Payesh (Health Monitor) 7 (4):355-62.

[23] Sadighi J, Maftoon F, Moshrefi M (2004) Complementary and alternative medicine (CAM): Knowledge, attitude and practice in Tehran, Iran. Payesh (Health Monitor) 3 (4):279-89.

[24] Zafarghandi N, Pirasteh A, Khajavi K, Bateni F (2012) Knowledge, Attitude and Behaviors of People Referred to Health Centers of Tehran About Iranian Traditional Medicine. Alborz University Medical Journal 1 (2):65-70.

Citation: Jamshid Ayatollahi, Seyed Hossein Shahcheraghi, et al. The Prevalence and Reasons of Tendency to Traditional Medicine. Open Access Journal of Internal Medicine. 2020; 3(1): 22-28.

Copyright: (C) 2020 Jamshid Ayatollahi, Seyed Hossein Shahcheraghi, et al. This is an open access article distributed under the Creative Commons Attribution License, which permits unrestricted use, distribution, and reproduction in any medium, provided the original work is properly cited. 